\title{
PENERAPAN ALGORITMA CERTAINTY FACTOR UNTUK SISTEM PAKAR DIAGNOSIS URTIKARIA PADA WANITA DEWASA
}

\author{
Fhariq Aulady ${ }^{1}$, A. Gunawan², Muhamad Ryansyah ${ }^{3}$ \\ 1,3STMIK Nusa Mandiri \\ e-mail: Fharigau0312@nusamandiri.ac.id ${ }^{1}$, muhamad.mur@nusamandiri.ac.id ${ }^{3}$ \\ 2Universitas Bina Sarana Informatika \\ e-mail: a.gunawan.agn@bsi.ac.id
}

\begin{abstract}
Abstrak
Penerapan Algoritma Certainty Factor Untuk Sistem Pakar Diagnosis Urtikaria Pada Wanita Dewasa. Urtikaria adalah reaksi pada kulit akibat bermacam-macam sebab, sinonim penyakit ini adalah biduran, kaligata, hives, nettle rash. Ditandai oleh edema (bengkak) setempat yang timbul secara mendadak dan menghilang perlahan-lahan berwarna kemerahan dan pucat, meninggi di permukaan kulit, sekitarnya dapat dikelilingi halo (bulatan). Angka kejadian urtikaria cukuplah tinggi sebanyak $15 \%-20 \%$ penduduk pernah mengalami urtikaria dalam kehidupannya dan $25 \%$ diantaranya mengalami urtikaria kronik, penyakit ini lebih banyak dijumpai pada perempuan. Pada penerapan ini dibuat sistem pakar menggunakan Certainty Factor. Dengan aplikasi sistem pakar diagnosis urtikaria pada wanita dewasa diharapkan dapat membantu memasyarakatkan pengetahuan dan pengalaman pakar-pakar yang ahli dibidangnya, mengetahui tingkatan penyakit berdasarkan gejala-gejala yang dialami dari penyakit urtikaria, tidak memerlukan biaya, menghemat waktu dalam pengambilan keputusan dan integrasi aplikasi sistem pakar lebih efektif mencakup aplikasi yang lebih luas.
\end{abstract}

Kata kunci: Sistem Pakar, Certainty Factor, Urtikaria, Aplikasi Mobile

\begin{abstract}
Application of the Certainty Factor Algoritm for urticarial diagnostic system experts in adult women. Urticaria is a reaction to the skin due to various causes, synonyms of this disease are biduran, chilblains, hives, nettle rash. Marked by local edema (swelling) that arises suddenly and disappears slowly reddish and pale, rising on the surface of the skin, the surroundings can be surrounded by halo (spherical). The incidence of urticaria is quite high as much as $15 \%-20 \%$ of the population has experienced urticaria in their lives and $25 \%$ of them experience chronic urticaria, this disease is more common in women. In this application an expert system is created using Certainty Factor. With the application of an expert system of diagnosis of urticaria in adult women is expected to help popularize the knowledge and experience of experts who are experts in their fields, know the level of disease based on the symptoms experienced from urticaria, no need for cost, save time in decision making and integration of expert system applications more effective covering wider applications.
\end{abstract}

Keywords: Expert System, Certainty Factor, Urticaria, Mobile Application 


\section{Pendahuluan}

Urtikaria adalah reaksi pada kulit akibat bermacam-macam sebab. Sinonim penyakit ini adalah biduran, kaligata, hives, nettle rash. Ditandai oleh edema (bengkak) setempat yang timbul secara mendadak dan menghilang perlahan-lahan, berwarna kemerahan dan pucat, meninggi di permukaan kulit, sekitarnya dapat dikelilingi halo (bulatan). Angka kejadian urtikaria cukuplah tinggi sebanyak 15\%-20\% penduduk pernah mengalami urtikaria dalam kehidupannya dan $25 \%$ diantaranya mengalami urtikaria kronik (Brahmanti, H., Rofiq, A., \& Cholis, 2017)

Untuk menyelesaikan suatu masalah ketidakpastian data. faktor kepastian diperkenalkan oleh Shortlife Buchanan dalam pembuatan MYCIN Certainty factor merupakan nilai parameter klinis yang diberikan MYCIN. (Halim \& Hansun, 2015)

Menurut Turban dalam (Ulya, D., Regasari, R., \& Furqon, 2014) menyatakan bahwa konsep dasar sistem pakar yang mengandung beberapa unsur, yaitu: kepakaran/keahlian, pakar/ahli pengalihan kepakaran/keahlian, inferensi, aturan dan kemampuan menjelaskan. Menggunakan certainty factor (CF) guna menggambarkan tingkat keyakinan pakar terhadap masalah yang sedang dihadapi. (Ulya, D., Regasari, R., \& Furqon, 2014)

Android adalah sebuah sistem operasi untuk perangkat mobile berbasis linux yang mencakup aplikasi, middle-ware dan sistem operasi. Android menyediakan sebuah platform terbuka bagi para pengembang untuk menciptakan aplikasi mereka (Supiandi, A., \& Chandradimuka, 2018)

\section{Metode Penelitian}

\section{A. Observasi}

Dalam penyusunan skripsi ini, dilakukan pengamatan langsung/observasi dengan mengumpulkan beberapa data pada wanita dewasa yang terjangkit penyakit urtikaria di dua tempat berbeda diantaranya di Klinik Jalur Farma Kota Sukabumi dan Puskesmas Pabuaran Kota Sukabumi.

\section{B. Wawancara}

Selain itu juga, dilakukan wawancara langsung terhadap para pakar yang sudah memiliki pengalaman dan pengetahuan khusus dalam bidang medis diantaranya dr. Tri
Betawihanta, dr Akbar Fauzi dan dr. Aiwi Japanesa.

\section{Studi Pustaka}

Pada metode ini, dilakukan pencarian dan pembelajaran dari berbagai macam literatur dan dokumen yang menunjang penyusunan skripsi ini, diantaranya dari buku, artikel ilmiah, Bahkan tidak menutup kemungkinan peneliti juga mencari data dokumen melalui internet yang tetap memperlihatkan kebenaran informasinya sehingga diperoleh data-data yang dapat dipertanggung jawabkan kebenarannya dalam sistem pakar ini.

"Dalam hal pengembangan serta perencanaan sistem harus beradaptasi dengan lingkungan baru, tahap pemeliharaan dapat mengulangi proses pengembangan mulai dari analisis spesifikasi untuk perubahan perangkat lunak yang sudah ada. Tapi tidak untuk membuat perangkat lunak baru. Perangkat lunak penyusun menggunakan metode pengembangan perangkat lunak model air terjun (waterfall)". (Awan Sagita \& Sugiarto, 2016)

\section{a. Analisa Kebutuhan Sistem}

Dari beberapa perangkat teknologi yang sudah ada program sistem pakar diagnosis penyakit urtikaria pada wanita dewasa ini akan diaplikasikan ke dalam perangkat mobile dengan sistem operasi android karena perangkat mobile dengan sistem operasi android semakin populer dan semakin banyak penggunanya.

\section{b. Desain}

Dikarenakan program ini akan diterapkan dalam sistem operasi Android, maka proses desain interface dari program sistem pakar ini menggunakan Eclipse yang ditambahkan dengan SDK (Software Developmnet Kit) Android.

\section{c. Testing}

Dalam pengujian sistemnya menggunakan metode Blackbox yang diimplementasikan menggunakan tabel pakar,dan Penanganan Ketidakpastiannya menggunakan Certainty Factor.

\section{d. Implementasi}

Pada tahapan ini dilakukan kegiatan spesifikasi rancangan logika ke dalam kegiatan yang sebenarnya dari sistem pakar yang akan dibangun atau dikembangkan, lalu mengimplementasikan sistem yang baru 
tersebut kedalam salah satu bahasa pemrograman yang berbasis android.

\section{e. Certainty Factor}

Menurut Stephanie Halim dan Seng Hansun (2015:61-62) mengemukakan bahwa "Metode certainty factor digunakan ketika menghadapi suatu masalah yang jawabannya tidak pasti. Ketidakpastian ini bisa merupakan probabilitas. Metode ini diperkenalkan oleh Shortlife Buchanan pada tahun 1970-an. Beliau menggunakan metode ini saat melakukan diagnosis dan terapi terhadap penyakit meningitis dan infeksi darah. Tim pengembang dari metode ini mencatat bahwa, dokter sering kali menganalisa informasi yang ada dengan ungkapan seperti "mungkin", "hampir pasti". Metode ini mirip dengan fuzzy logic, karena ketidakpastian direpresentasikan dengan derajat kepercayaan sedangkan perbedaannya adalah pada fuzzy logic saat perhitungan untuk rule yang premisnya lebih dari satu, fuzzy logic tidak memiliki nilai keyakinan untuk rule tersebut sehingga perhitungannya hanya melihat nilai terkecil untuk operator AND atau nilai terbesar untuk operator OR dari setiap premis yang pada rule tersebut berbeda dengan certainty factor yaitu setiap rule memiiki nilai keyakinannya sendiri tidak hanya premis-premisnya saja yang memiliki nilai keyakinan. Certainty factor menunjukkan ukuran kepastian terhadap suatu fakta atau aturan.

$\begin{array}{lll}C F[h, e] & M B[h, e] \\ M D[h, e] \ldots \ldots \ldots \ldots \ldots \ldots \ldots \ldots \ldots \ldots \ldots \ldots . . . & (1)\end{array}$

Keterangan :

$C F[h, e]=$ faktor kepastian

$M B[h, e]=$ measure of belief, ukuran kepercayaan atau tingkat keyakinan terhadap hipotesis (h), jika diberikan evidence (e) antara 0 dan 1

$M D[h, e]=$ measure of disbelief, ukuran ketidakpercayaan atau tingkat keyakinan terhadap hipotesis (h), jika diberikan evidence (e) antara 0 dan 1. Adapun beberapa kombinasi certainty factor terhadap premis tertentu:

Berikut ini adalah deskripsi beberapa kombinasi Certainty Factor terhadap berbagai kondisi :

Certainty Factor untuk kaidah dengan premis tunggal :

$$
C F(H, E)=C F(E){ }^{*} C F(\text { rule })
$$

CF(user)

$C F($ pakar).

Certainty Factor untuk kaidah dengan premis majemuk :

$C F(A$ AND B $)=\operatorname{Minimum}(C F(a), C F(b)){ }^{*} C F$ (rule)

$C F(A$ OR B $)=$ Maximum (CF (a), $C F(b)) * C F$ (rule).

Certainty Factor untuk kaidah dengan kesimpulan yang serupa :

CFCOMBINE (CF1, CF2) $=C F 1+C F 2 *(1-$ CF1).

\section{Hasil dan Pembahasan}

\section{1.Pengumpulan Data Pakar}

Dalam pembuatan sistem pakar berbasis mobile computing ini diperlukan sistematika gejala urtikaria berupa tabel yang bertujuan mempermudah dalam perancangan. Tabel ini dapat mempermudah dalam memahami serta dengan cepat mengetahui tingkat gejala urtikaria. Dalam penelitian identifikasi urtikaria pada wanita dewasa ini terdapat 9 gejala dan 3 klasifikasi, berikut ini adalah tabelnya :

Tabel 1. Tabel Pakar

Gejala dan klasifikasi Gejala Urtikaria

\begin{tabular}{|c|c|c|c|c|}
\hline No & $\begin{array}{l}\text { Gejala } \\
\text { penyakit } \\
\text { Urtikaria }\end{array}$ & $\begin{array}{c}\text { Urtikari } \\
\text { a } \\
\text { Sponta } \\
n\end{array}$ & $\begin{array}{l}\text { Urtikari } \\
\text { a Akut }\end{array}$ & $\begin{array}{c}\text { Urtikari } \\
\text { a } \\
\text { Kronis }\end{array}$ \\
\hline 1. & $\begin{array}{l}\text { Ada rasa gatal } \\
\text { tetapi tidak } \\
\text { mengganggu } \\
\text { alias gejala } \\
\text { normal }\end{array}$ & 0 & & \\
\hline 2. & $\begin{array}{l}\text { Ditemukan } \\
\text { lesi/peninggia } \\
\text { n kulit (bentol) } \\
\text { dengan } \\
\text { ukuran } \\
\text { bervariasi } \\
\text { diarea } \\
\text { Tangan/Kaki/ } \\
\text { Muka dan bisa } \\
\text { disertai } \\
\text { kemerahan }\end{array}$ & 0.4 & & \\
\hline 3. & $\begin{array}{l}\text { Terjadinya lesi } \\
\text { kulit 1-24 jam, } \\
\text { pencetus } \\
\text { terjadinya } \\
\text { karena kontak } \\
\text { fisik dengan } \\
\text { udara } \\
\text { dingin/panas, } \\
\text { tekanan/gores }\end{array}$ & 0.45 & & \\
\hline
\end{tabular}


JURNAL SWABUMI, Vol. 7 No.1 Maret 2019, pp. 90 98

ISSN: 2355-990X

E-ISSN:2549-5178

93

\begin{tabular}{|c|c|c|c|}
\hline & $\begin{array}{l}\text { an, } \\
\text { serangga/bina } \\
\text { tang, air, } \\
\text { peningkatan } \\
\text { suhu tubuh } \\
\text { akibat } \\
\text { olahraga/mak } \\
\text { anan pedas } \\
\text { atau yang } \\
\text { lainnya }\end{array}$ & & \\
\hline 4. & $\begin{array}{l}\text { Ada rasa gatal } \\
\text { yang } \\
\text { mengganggu, } \\
\text { tetapi tidak } \\
\text { mempengaruh } \\
\text { i tidur atau } \\
\text { aktivitas } \\
\text { sehari-hari } \\
\end{array}$ & 0.5 & \\
\hline 5. & $\begin{array}{l}\text { Ditemukan } \\
\text { lesi/peninggia } \\
\mathrm{n} \text { kulit (bentol) } \\
\text { dengan } \\
\text { ukuran } \\
\text { bervariasi } \\
\text { diarea badan } \\
\text { disertai } \\
\text { kemerahan } \\
\text { dan rasa } \\
\text { panas }\end{array}$ & 0.6 & \\
\hline 6. & $\begin{array}{l}\text { Terjadinya lesi } \\
\text { kulit kurang } \\
\text { dari <6 } \\
\text { minggu, } \\
\text { pencetus } \\
\text { terjadinya } \\
\text { karena kontak } \\
\text { fisik dengan } \\
\text { udara } \\
\text { dingin/panas, } \\
\text { tekanan/gores } \\
\text { an, } \\
\text { serangga/bina } \\
\text { tang, air, } \\
\text { peningkatan } \\
\text { suhu tubuh } \\
\text { akibat } \\
\text { olahraga/mak } \\
\text { anan pedas } \\
\text { atau yang } \\
\text { lainnya }\end{array}$ & 0.65 & \\
\hline 7. & $\begin{array}{l}\text { Ada rasa gatal } \\
\text { yang hebat, } \\
\text { menganggu } \\
\text { dan } \\
\text { mempengaruh } \\
\text { i tidur atau } \\
\text { aktivitas } \\
\text { sehari-hari }\end{array}$ & & 0.75 \\
\hline 8. & $\begin{array}{l}\text { Ditemukan } \\
\text { lesi/peninggia } \\
\mathrm{n} \text { kulit (bentol) } \\
\text { dengan } \\
\text { ukuran } \\
\text { bervariasi } \\
\text { diseluruh } \\
\text { tubuh disertai } \\
\text { kemerahan } \\
\text { dan sensasi } \\
\text { terbakar }\end{array}$ & & 0.8 \\
\hline 9. & $\begin{array}{l}\text { Terjadinya lesi } \\
\text { kulit lebih dari }\end{array}$ & & 0.85 \\
\hline
\end{tabular}

$>6$ minggu,

pencetus

terjadinya

karena kontak

fisik dengan

udara

dingin/panas,

tekanan/gores

an,

serangga/bina

tang, air,

peningkatan

suhu tubuh

akibat

olahraga/mak

anan pedas

atau yang

lainnya

\subsection{Algoritma Sistem Pakar}

Rancangan algoritma dalam perancangan ini menggunakan metode Certainty Factor. Berikut ini adalah deskripsi beberapa kombinasi Certainty Factor yang diterapkan pada aplikasi sebagai berikut :

1. Certainty Factor dengan satu premis (single premis rules) :

$$
\begin{aligned}
& \begin{aligned}
C F(\text { h,e }) & C F(E) * C F(\text { rule) } \\
= & * 0=0 \% \text { (Urtikaria Spontan) } \\
= & * 0.4=40 \% \text { (Urtikaria }
\end{aligned} \\
& \begin{array}{r}
\text { Spontan) } \\
=1 * 0.45=45 \% \text { (Urtikaria }
\end{array} \\
& \begin{array}{r}
\text { Spontan) } \\
=1 * 0.5=50 \% \text { (Urtikaria Akut) } \\
=1 * 0.6=60 \% \text { (Urtikaria Akut) } \\
=1 * 0.65=65 \% \text { (Urtikaria Akut) } \\
=1 * 0.75=75 \% \text { (Urtikaria Kronis) } \\
=1 * 0.8=80 \% \text { (Urtikaria }
\end{array} \\
& \begin{array}{r}
\text { Kronis) } \\
=1
\end{array}
\end{aligned}
$$

2. Certainty Factor untuk kaidah dengan kesimpulan yang serupa (similarly concluded rules) :

CFCOMBINE (CF1, CF2) $=C F 1+C F 2^{*}(1$ $-C F 1)$

$=0+0.4^{*}(1-0)=0.4$

$=0.4+0.45^{*}(1-0.4)=0.67=67 \%$

(Urtikaria Spontan)

$=0.5+0.6^{*}(1-0.5)=0.8$

$=0.8+0.65^{*}(1-0.8)=0.93=93 \%$

(Urtikaria Akut)

$=0.75+0.8^{*}(1-0.75)=0.95$

$=0.95+0.85^{*}(1-0.95)=0.9925=99 \%$

(Urtikaria Kronis) 


\subsection{Basis Pengetahuan}

Basis pengetahuan terbentuk atas fakta-fakta berupa informasi tentang cara menimbulkan suatu fakta baru dari fakta yang sudah diketahui. Pengetahuan ini adalah suatu representasi pengetahuan dan cara suatu pendekatan pemikiran dari seorang pakar.

1. Rule-Rule Pada Pakar

Aturan-aturan atau rule yang diperoleh sebagai berikut:

a. Aturan Penyakit Urtikaria Spontan

Ada rasa gatal tetapi tidak mengganggu alias gejala normal AND Ditemukan lesi/peninggian kulit (bentol) dengan ukuran bervariasi diarea Tangan/Kaki/Muka dan bisa disertai kemerahan AND Terjadinya lesi kulit 1-24 jam, pencetus terjadinya karena kontak fisik dengan udara dingin/panas, tekanan/goresan, serangga/binatang, air, peningkatan suhu tubuh akibat olahraga/makanan pedas atau yang lainnya THEN Urtikaria Spontan.

b. Aturan Penyakit Urtikaria Akut

Ada rasa gatal yang mengganggu, tetapi tidak mempengaruhi tidur atau aktivitas seharihari AND Ditemukan lesi/peninggian kulit (bentol) dengan ukuran bervariasi diarea badan disertai kemerahan dan rasa panas AND Terjadinya lesi kulit kurang dari $<6$ minggu, pencetus terjadinya karena kontak fisik dengan udara dingin/panas, tekanan/goresan, serangga/binatang, air, peningkatan suhu tubuh akibat olahraga/makanan pedas atau yang lainnya THEN Urtikaria Akut

c. Aturan Penyakit Urtikaria Kronis

Ada rasa gatal yang hebat, menganggu dan mempengaruhi tidur atau aktivitas seharihari

AND Ditemukan lesi/peninggian kulit (bentol) dengan ukuran bervariasi diseluruh tubuh disertai kemerahan dan sensasi terbakar AND Terjadinya lesi kulit lebih dari $>6$ minggu, pencetus terjadinya karena kontak fisik dengan udara dingin/panas, tekanan/goresan, serangga/binatang, air, peningkatan suhu tubuh akibat olahraga/makanan pedas atau yang lainnya THEN Urtikaria Kronis

\subsection{Pohon Keputusan Pakar}

Setelah didapatkan aturan-aturan atau rule tersebut maka pohon keputusan yang terbentuk dapat dilihat seperti gambar di bawah ini:

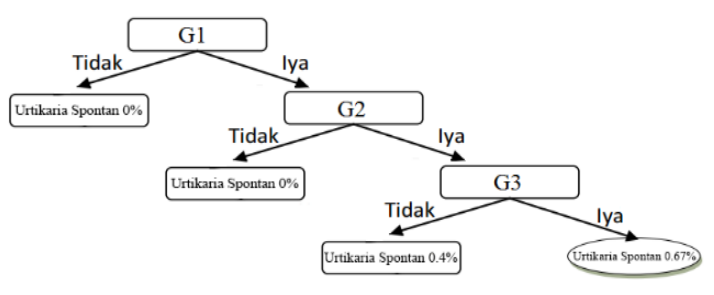

Gambar 1. Pohon Keputusan Urtikaria Spontan

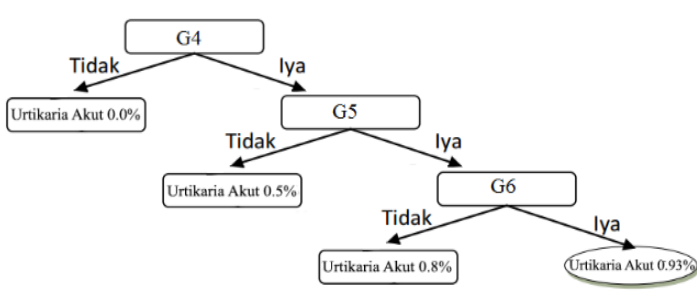

Gambar 2. Pohon Keputusan Urtikaria Akut

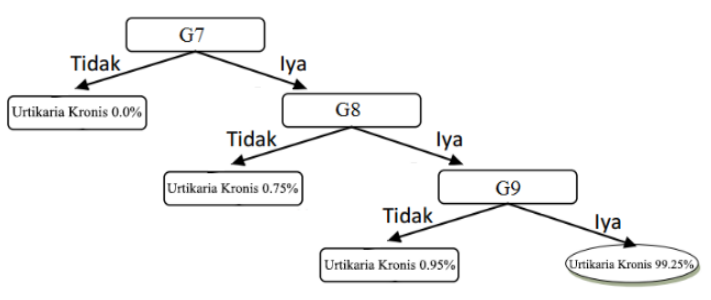

Gambar 3. Pohon Keputusan Urtikaria Kronis

\subsection{Software Architecture}

\section{A. Pseudocode}

Nama : Proses Diagnosa

Fungsi : Menentukan Gejala Klasifikasi Penyakit

Urtikaria Berdasarkan CF Pakar dan CF User

Input : CF Pakar dan CF User

Output : :Tingkatan Penyakit

if(stringBuilder.toString().trim().equals(“Gejala8”)) \{

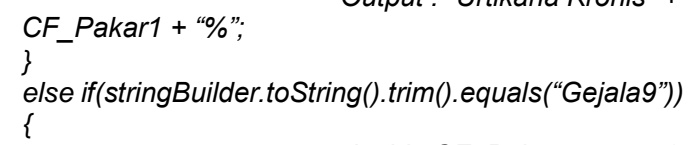


JURNAL SWABUMI, Vol. 7 No.1 Maret 2019, pp. 90 98

ISSN: 2355-990X

E-ISSN:2549-5178

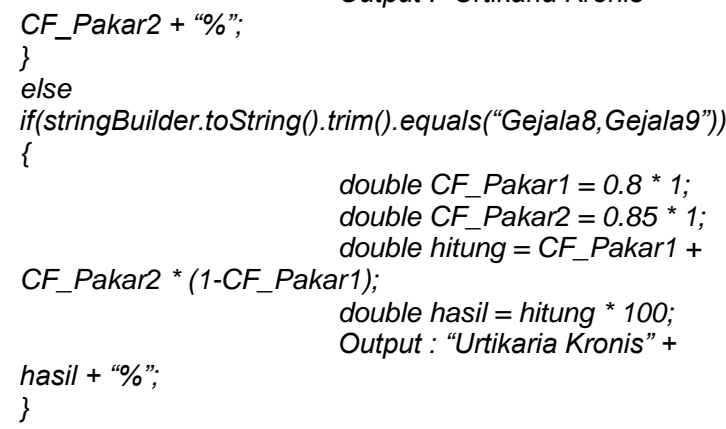

\section{B. Permodelan UML}

Dalam memodelkan proses yang terjadi pada rancangan sistem aplikasi diagnosa penyakit udang galah akan dibuat ke dalam bentuk UML yaitu, use case diagram, activity diagram, sequance diagram, dan deployment diagram.

\section{Usecase Diagram}

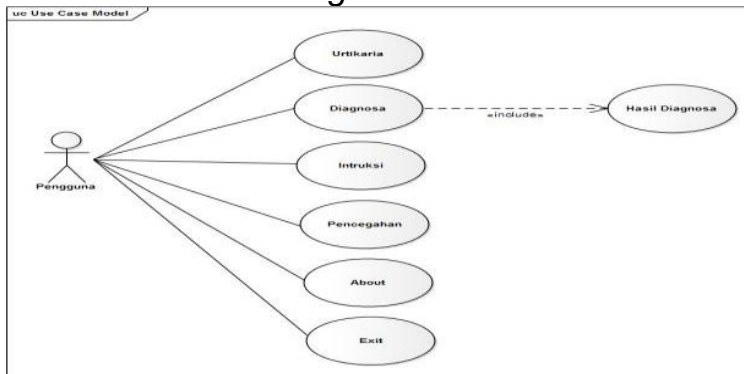

Gambar 5. Use Case Diagram Diagnosa Penyakit Urtikaria

Tabel 2. Deskripsi Use Case Diagram Urtikaria

\begin{tabular}{|c|c|}
\hline Use Case Name & Urtikaria \\
\hline Requirment & A1 \\
\hline Goal & $\begin{array}{l}\text { Pengguna dapat melihat } \\
\text { informasi mengenai penyakit } \\
\text { urtikaria dan gambar penyakit } \\
\text { urtikaria }\end{array}$ \\
\hline Pre-condition & $\begin{array}{l}\text { Pengguna memilih menu } \\
\text { utama }\end{array}$ \\
\hline Post-condition & $\begin{array}{l}\text { Tampil informasi mengenai } \\
\text { penyakit urtikaria dan gambar } \\
\text { penyakit urtikaria }\end{array}$ \\
\hline $\begin{array}{l}\text { Failed end } \\
\text { condition }\end{array}$ & $\begin{array}{l}\text { Pengguna tidak memilih menu } \\
\text { urtikaria }\end{array}$ \\
\hline Primary Actor & Pengguna \\
\hline $\begin{array}{l}\text { Main Flow/Basic } \\
\text { Path }\end{array}$ & $\begin{array}{l}\text { Pengguna memilih menu } \\
\text { urtikaria }\end{array}$ \\
\hline Invariant & - \\
\hline
\end{tabular}

Tabel 3. Deskripsi Use Case Diagram Diagnosa

\begin{tabular}{ll}
\hline Use Case Name & Menu Diagnosa \\
\hline Requirment & A2 \\
Goal & $\begin{array}{l}\text { Pengguna mendapatkan hasil } \\
\text { diagnosa }\end{array}$ \\
Pre-condition & $\begin{array}{l}\text { Pengguna memilih menu } \\
\text { diagnosa }\end{array}$ \\
Post-condition & Tampil hasil diagnosa \\
Failed end & Pengguna tidak memilih menu \\
condition & diagnosa \\
Primary Actor & Pengguna \\
Main Flow/Basic & Pengguna memilih menu \\
Path & diagnosa \\
Invariant & -
\end{tabular}

Tabel 4. Deskripsi Use Case Diagram Intruksi

\begin{tabular}{|c|c|}
\hline Use Case Name & Intruksi \\
\hline Requirment & A3 \\
\hline Goal & $\begin{array}{l}\text { Pengguna dapat melihat cara } \\
\text { menggunakan aplikasi } \\
\text { diagnosa urtikaria }\end{array}$ \\
\hline Pre-condition & $\begin{array}{l}\text { Pengguna memilih menu } \\
\text { utama }\end{array}$ \\
\hline Post-condition & $\begin{array}{l}\text { Tampil informasi mengenai } \\
\text { intruksi penggunaan aplikasi } \\
\text { diagnosa urtikaria }\end{array}$ \\
\hline Failed end condition & $\begin{array}{l}\text { Pengguna tidak memilih menu } \\
\text { intruksi }\end{array}$ \\
\hline Primary Actor & Pengguna \\
\hline $\begin{array}{l}\text { Main Flow/Basic } \\
\text { Path }\end{array}$ & $\begin{array}{l}\text { Pengguna memilih menu } \\
\text { intruksi }\end{array}$ \\
\hline Invariant & - \\
\hline
\end{tabular}

Tabel 5. Deskripsi Use Case Diagram Pencegahan

\begin{tabular}{ll}
\hline Use Case Name & Pencegahan \\
\hline Requirment & A4 \\
Goal & $\begin{array}{l}\text { Pengguna dapat melihat } \\
\text { Pencegahan }\end{array}$ \\
& Pengguna memilih menu utama \\
Pre-condition & Tampil pencegahan \\
Post-condition & Pengguna tidak memilih menu \\
Failed end & pencegahan \\
condition & Pengguna \\
Primary Actor & Pengguna memilih menu \\
Main Flow/Basic & pencegahan \\
Path & - \\
Invariant & \\
\hline
\end{tabular}

Tabel 6. Deskripsi Use Case Diagram Tentang

\begin{tabular}{ll}
\hline Use Case Name & Tentang \\
\hline Requirment & A5 \\
Goal & $\begin{array}{l}\text { Pengguna dapat melihat } \\
\text { informasi mengenai versi } \\
\text { program dan nama } \\
\text { pembuatnya }\end{array}$ \\
Pre-condition & $\begin{array}{l}\text { Pengguna memilih menu utama } \\
\text { Pon }\end{array}$
\end{tabular}


JURNAL SWABUMI, Vol. 7 No.1 Maret 2019, pp. 90 98

ISSN: 2355-990X

E-ISSN:2549-5178

\begin{tabular}{ll} 
Post-condition & $\begin{array}{l}\text { Tampil informasi mengenai } \\
\text { versi program dan nama } \\
\text { pembuatnya }\end{array}$ \\
$\begin{array}{l}\text { Failed end } \\
\text { condition }\end{array}$ & $\begin{array}{l}\text { Pengguna tidak memilih menu } \\
\text { tentang }\end{array}$ \\
Primary Actor & Pengguna \\
Main Flow/Basic & Pengguna memilih menu \\
Path & tentang \\
Invariant & - \\
\hline
\end{tabular}

\section{Activity Diagram}

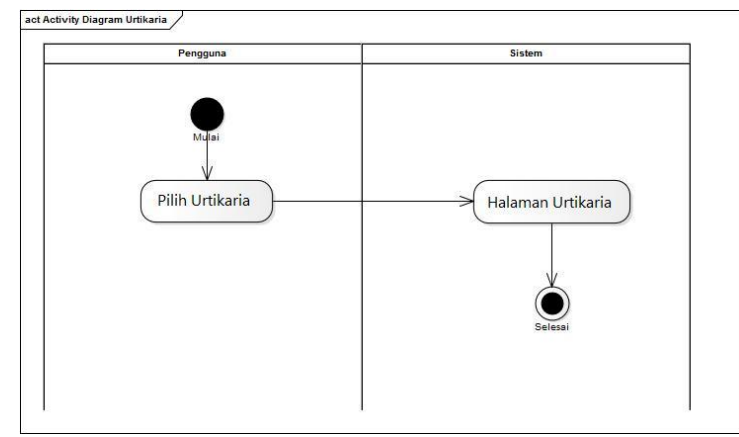

Gambar 6. Activity Diagram Menu Diagnosa

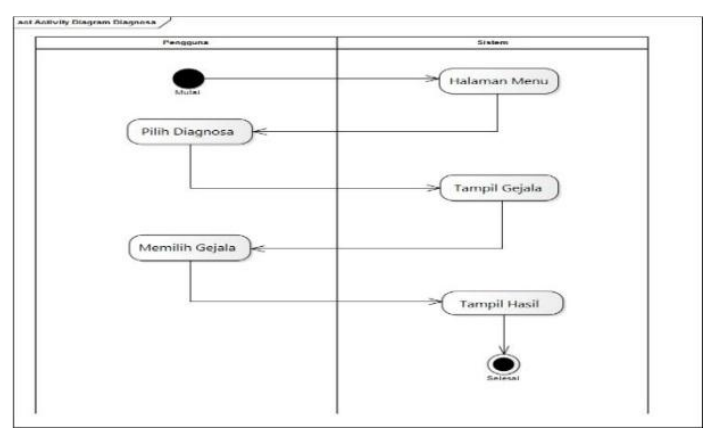

Gambar 7. Activity Diagram Diagnosa

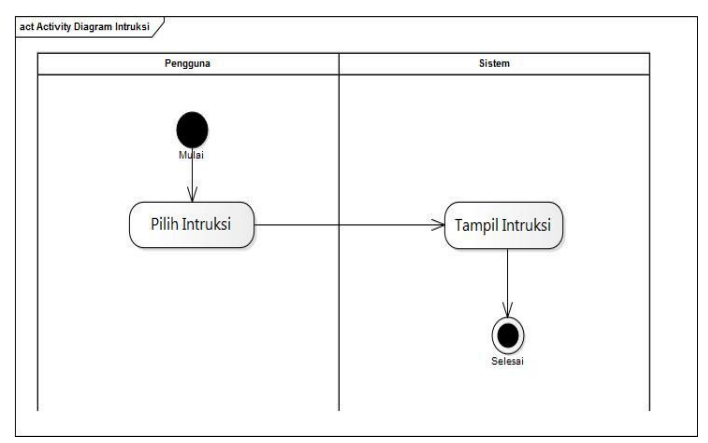

Gambar 8. Activity Diagram Intruksi

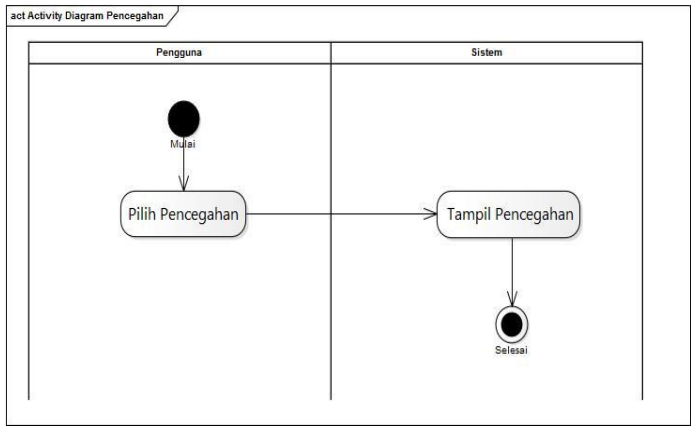

Gambar 9. Activity Diagram Pencegahan

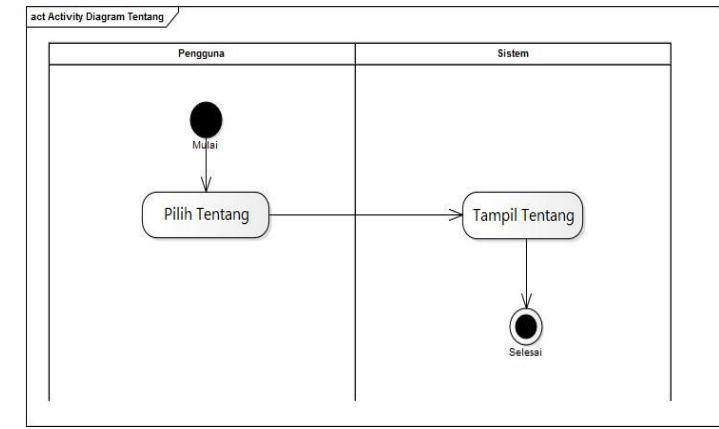

Gambar 10. Activity Diagram Tentang Squence Diagram

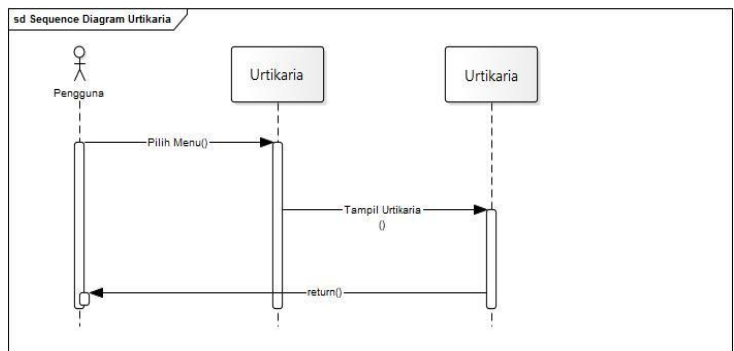

Gambar 11. Squence Diagram Urtikaria

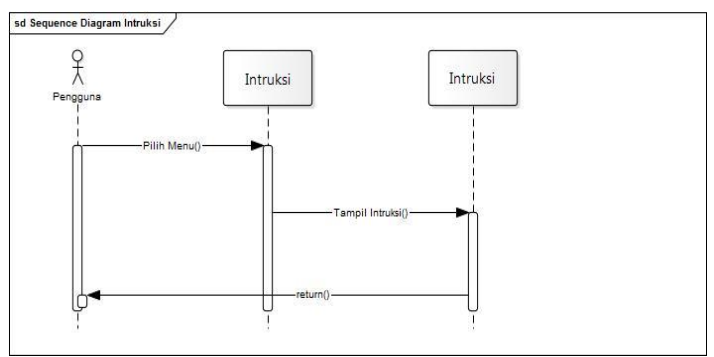

Gambar 12. Squence Diagram Pencegahan 
JURNAL SWABUMI, Vol. 7 No.1 Maret 2019, pp. 90 98

ISSN: 2355-990X

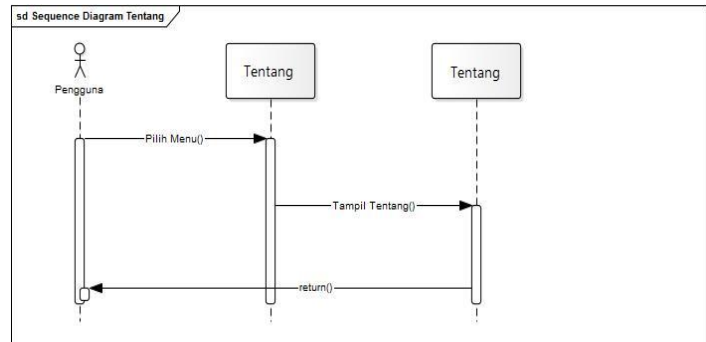

Gambar 13. Squence Diagram Tentang

\section{User Interface}

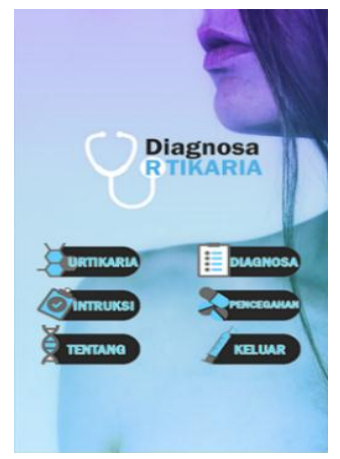

Gambar 14. Menu

Halaman utama untuk masuk ke menu yang akan d pilih

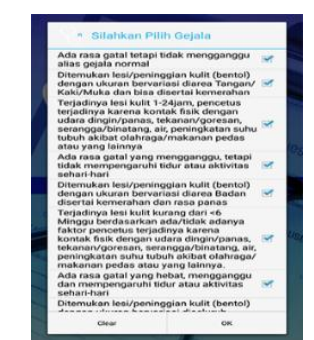

Gambar 15. Diagnosa

Halaman ini menampilkan hasil dari diagnosa

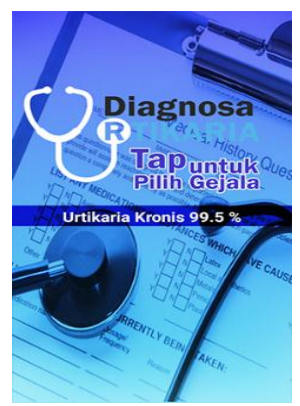

Gambar 16. Hasil
Hasil persentasi dari gejala yang telah dilakukan

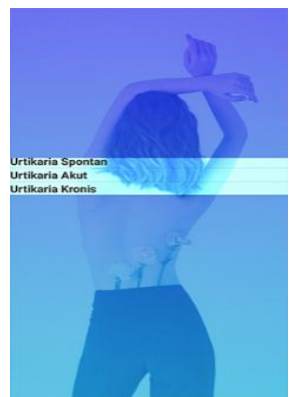

Gambar 17. Pencegahan

Tampilan dari penyakit yang timbil disertai pencegahan

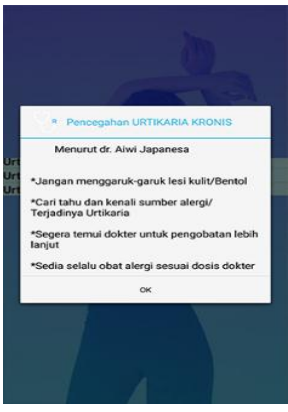

Gambar 18. Deskripsi

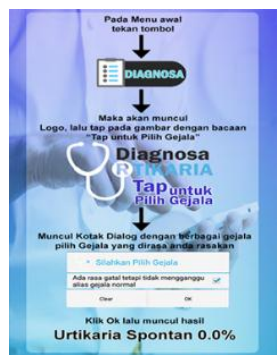

Gambar 19. Intruksi

Tampilan halaman untuk melakukan instruksi kembali

\subsection{BlackBox Testing}

Metode ini digunakan untuk mengetahui apakah perangkat lunak berfungsi dengan benar. Adapun hal-hal yang akan diujikan menggunakan metode black box ini adalah sebagai berikut : 
JURNAL SWABUMI, Vol. 7 No.1 Maret 2019, pp. 90 98

ISSN: 2355-990X

E-ISSN:2549-5178

98

Tabel 7. Pengujian Urtikaria

\begin{tabular}{cccc}
\hline $\begin{array}{c}\text { Data } \\
\text { Masukkan }\end{array}$ & $\begin{array}{c}\text { Yang } \\
\text { diharapkan }\end{array}$ & Pengamatan & Kesimpulan \\
\hline Klik & Muncul & Muncul & Sesuai \\
Urtikaria & $\begin{array}{c}\text { Informasi } \\
\text { Urtikaria }\end{array}$ & $\begin{array}{c}\text { Informasi } \\
\text { Urtikaria }\end{array}$ & \\
& Unta &
\end{tabular}

Sumber: (Aulady;Gunawan;Ryansyah, 2018)

Tabel 8. Pengujian Menu Diagnosa

\begin{tabular}{|c|c|c|c|}
\hline $\begin{array}{c}\text { Data } \\
\text { Masukkan }\end{array}$ & $\begin{array}{c}\text { Yang } \\
\text { diharapkan }\end{array}$ & Pengamatan & Kesimpulan \\
\hline $\begin{array}{l}\text { Klik } \\
\text { Diagnosa }\end{array}$ & $\begin{array}{l}\text { Muncul } \\
\text { Pilih } \\
\text { Gejala } \\
\text { Penyakit }\end{array}$ & $\begin{array}{l}\text { Muncul Pilih } \\
\text { Gejala } \\
\text { Penyakit }\end{array}$ & Sesuai \\
\hline $\begin{array}{l}\text { Memilih } \\
\text { Gejala } \\
\text { Penyakit } \\
\text { dari } \\
\text { Daftar Ialu } \\
\text { klik } \\
\text { "Ok" }\end{array}$ & $\begin{array}{l}\text { Muncul } \\
\text { Jenis } \\
\text { Penyakit } \\
\text { serta } \\
\text { Persentase } \\
\text { nya }\end{array}$ & $\begin{array}{l}\text { Muncul } \\
\text { Jenis } \\
\text { Penyakit } \\
\text { serta } \\
\text { Persentasen } \\
\text { ya }\end{array}$ & Sesuai \\
\hline \multicolumn{4}{|c|}{ Tabel 9. Pengujian Intruksi } \\
\hline $\begin{array}{c}\text { Data } \\
\text { Masukkan }\end{array}$ & $\begin{array}{c}\text { Yang } \\
\text { diharapkan }\end{array}$ & Pengamatan & Kesimpulan \\
\hline $\begin{array}{l}\text { Klik } \\
\text { Intruksi }\end{array}$ & $\begin{array}{l}\text { Muncul } \\
\text { Intruksi }\end{array}$ & $\begin{array}{l}\text { Muncul } \\
\text { Intruksi }\end{array}$ & Sesuai \\
\hline
\end{tabular}

Tabel 10. Pengujian Pencegahan untuk penyelesaian suatu masalah diagnosis penyakit urtikaria.

2. Mampu memberikan informasi tentang urtikaria, mengenali gejala-gejala yang ada pada penyakit urtikaria dengan aplikasi diagnosis urtikaria pada wanita dewasa berbasis mobile.

3. Aplikasi Sistem pakar ini mampu memberikan pengetahuan dini pada masyarakat agar mengetahui faktor tingkatan resiko dari penyakit urtikaria berbasis mobile.

\section{Referensi}

Aulady;Gunawan;Ryansyah.

Penerapan Algoritma Certainty Factor Untuk Sistem Pakar Diagnosis Urtikaria Pada Wanita Dewasa.

Awan Sagita, R., \& Sugiarto, H. (2016). Penerapan Metode Waterfall Pada Sistem Informasi Penjualan Furniture Berbasis Web, 49-55.

Brahmanti, H., Rofiq, A., \& Cholis, M. (2017).

\begin{tabular}{lllll}
\hline \multicolumn{1}{c}{$\begin{array}{c}\text { Data } \\
\text { Masukkan }\end{array}$} & $\begin{array}{c}\text { Yang } \\
\text { diharapkan }\end{array}$ & Pengamatan & Kesimpulan \\
& & & \\
\hline Klik & Muncul Pilih & Muncul pilih & Sesuai & \\
Pencegahan & Pencegahan & Pencegahan & & \\
\hline Memilih & Muncul & Muncul & Sesuai & \\
$\begin{array}{l}\text { Pencegahan } \\
\text { dari }\end{array}$ & Pencegahan & Pencegahan & & Hali \\
Daftar lalu & & & & \\
klik & & & \\
"Ok" & & & \\
\hline
\end{tabular}

Hubungan Antara Kadar Hormon Dehydroepiandrosterone Sulfate (Dheas) Serum Dengan Aktivitas Penyakit Urtikaria Kronis Pada Perempuan, 158-165.

Halim, S., \& Hansun, S. (2015). Penerapan Metode Certainty Factor dalam Sistem Pakar Pendeteksi Resiko Osteoporosis dan Osteoarthritis. ULTIMA Computing, VIII(2).

Supiandi, A., \& Chandradimuka, D. B. (2018).

Tabel 11. Pengujian Tentang

\begin{tabular}{llll}
\hline \multicolumn{1}{c}{ Data } & \multicolumn{1}{c}{ Yang } & Pengamatan & Kesimpulan \\
Masukkan & diharapkan & & \\
\hline Klik & Muncul & Muncul & Sesuai \\
Tentang & Tentang & Tentang & \\
\hline
\end{tabular}

\section{Kesimpulan}

Dapat diambil kesimpulan dari pembuatan aplikasi Sistem Pakar Diagnosa Penyakit Urtikaria Berbasis Mobile Dengan Metode Certainty Factor, diantaranya:

1. Faktor Keputusan dengan menggunakan metode Certainty Factor sangat cocok
Sistem Pakar Diagnosa Depresi Mahasiswa Akhir Dengan Metode Certainty Factor Berbasis Mobile, 5(1), 102-111.

Ulya, D., Regasari, R., \& Furqon, M. T. (2014). Sistem Pakar Diagnosa Penyakit Kulit Pada Anak Menggunakan Metode Certainty Factor. Sistem Pakar Diagnosa Penyakit Kulit Pada Anak Menggunakan Metode Certainty Factor, 1-11. 